\title{
Parâmetros para cobrança de custos e despesas pessoais (CNJ)
}

\author{
Conselho Nacional de Justiça (CNJ)
}

\section{PROCEDIMENTO DE COMISSÃO № 0000788-24.2012.2.00.0000 RELATOR: CONSELHEIRO JEFFERSON KRAVCHYCHYN}

\section{Vistos,}

Trata-se de procedimento de COMISSÃO instaurado pela Comissão de Eficiência Operacional e Gestão de Pessoas em atenção à deliberação deste Conselho Nacional de Justiça (CNJ), em face da decisão proferida no Procedimento de Controle Administrativo (PCA) no $0004149-54.2009 .2 .00 .0000$, que propôs a realização de estudos técnicos por um grupo de trabalho para apresentação de parâmetros para a cobrança de custas e despesas processuais. Vejamos a ementa desse julgado:

PROCEDIMENTO DE CONTROLE ADMINISTRATIVO. AUTO CIRCUNSTANCIADO DE INSPEÇÃO PREVENTIVA. ESTABELECIMENTO DE PARÂMETROS NA COBRANÇA DE CUSTAS E DESPESAS PROCESSUAIS. NOTA TÉCNICA ELABORADA PELO DPJ. PROPOSTA DE CRIAÇÃO DE GRUPO DE TRABALHO.

- Considerando-se o elevado grau de disparidades observado nas vinte e sete unidades da federação, o Conselho Nacional de Justiça pode atuar de modo a estabelecer linhas gerais com o fito de orientar que os Estados passem a adotar modelos de cobrança de custas mais adequadas que atuem como meio facilitador do acesso à justiça. 
- Para concretude do amplo estudo trazido, necessária seria a elaboração e encaminhamento de anteprojeto de lei ao Congresso Nacional, em respeito ao artigo 24, IV da Constituição Federal, que prevê que a edição de lei nacional aplicável a todo o País sobre custas dos serviços forenses compete à União.

- A adoção de legislação nacional sobre o assunto poderia uniformizar o conceito de custas e taxas judiciais, estabelecendo caracterizações e hipóteses de incidência de modo mais preciso, com vistas a nortear as legislações estaduais.

- Outra frente consiste na elaboração de Resolução ou Recomendação contendo minuta de projetos de leis para os Tribunais de Justiça e Assembleias Legislativas, no sentido de alterar as legislações estaduais sobre custas judiciais, com vistas à diminuição das mesmas, onde valores são altos e incompatíveis com a realidade social da população.

- Propõe-se a criação de um grupo de trabalho, composto por Conselheiros do $\mathrm{CNJ}$, magistrados e técnicos dos Tribunais pátrios, representantes da Ordem dos Advogados do Brasil, Ministério Público e Defensoria Pública, além dos servidores do Departamento de Pesquisas Judiciárias, e que deverá atuar, de forma conjunta com os Tribunais de Justiça, a fim de que proceda ao desenvolvimento de estudos técnicos para a formulação de parâmetros para a cobrança de custas e despesas processuais.

Em razão desse fato, foi editada a Portaria da Presidência do CNJ no 232, de 20 de dezembro de 2010, que instituiu "grupo de trabalho para elaborar estudos e apresentar propostas de medidas relativas ao regime de cobrança de custas no Poder Judiciário", composto por representantes da Justiça Estadual e da Ordem dos Advogados do Brasil (OAB).

O trabalho do grupo foi norteado pela pesquisa do Departamento de Pesquisas Judiciárias (DPJ) - "Perfil da fixação de custas judiciais no Brasil e análise comparativa da experiência internacional", que identificou os seguintes problemas: a) carência de uniformidade nos conceitos, critérios, modelos de custas judiciais; b) discrepância dos valores cobrados nas diversas unidades federativas; c) falta de transparência da legislação relativa a essa matéria; d) políticas regressivas na fixação de custas em alguns Estados, de modo a onerar em grau maior as classes econômicas inferiores; e) distorção entre valores praticados na $1^{\underline{a} \mathrm{a}}$ e na $2^{\underline{a}}$ instância (DOC3). 
Amplo debate foi promovido a fim de ouvir os Tribunais de Justiça, Corregedorias Estaduais e representantes da $\mathrm{OAB}$, por meio de reuniões regionais, realizadas em Goiânia, Curitiba, Belo Horizonte, Rio de Janeiro, João Pessoa, Belém e Manaus (Evento 13).

Concluída a fase de coleta de informações, foi apresentada versão inicial do anteprojeto da "Lei Geral das Custas Judiciais" (DOC 3, 4, 5 e 6) às Presidências dos Tribunais Estaduais, Federais, do Trabalho e Militares; ao Conselho Superior da Justiça do Trabalho; ao Conselho da Justiça Federal; às Associações Estaduais e Federais de Magistrados; ao Conselho Federal da Ordem dos Advogados do Brasil e Seções estaduais; e ao jurisdicionado nacional, solicitando manifestação, neste último caso, por meio de consulta pública.

Foram apresentadas cerca de 400 (quatrocentas) sugestões, manifestandose 23 (vinte e três) Tribunais Estaduais, o Conselho Superior da Justiça do Trabalho e 9 (nove) Tribunais Regionais do Trabalho, o Conselho da Justiça Federal e 2 (dois) Tribunais Regionais Federais e 5 (cinco) Seccionais da OAB.

Ante a análise e deliberação do grupo de trabalho e da Comissão de Eficiência Operacional e Gestão de Pessoas sobre as sugestões e críticas apresentadas, nova versão do anteprojeto foi elaborada, a qual trago para deliberação deste Conselho que, aquiescendo, encaminhará, como sugestão de iniciativa legislativa, ao Supremo Tribunal Federal.

\section{PROJETO DE LEI № , DE 2012}

Estabelece normas gerais para a cobrança de custas dos serviços forenses no âmbito da União, dos Estados, do Distrito Federal e Territórios, e o controle de sua arrecadação.

\section{O Congresso Nacional Decreta:}

Art. 1ํ. Esta Lei estabelece normas gerais para a cobrança de custas dos serviços forenses a que se referem os artigos 24 , inc. IV e 98,2 da Constituição Federal, no âmbito da União, dos Estados, do Distrito Federal e Territórios, e o controle de sua arrecadação. 
Art. 2. Respeitado o direito assegurado pelo art. 5º, inc. LXXIV da Constituição Federal à assistência jurídica integral e gratuita aos que comprovarem insuficiência de recursos, as custas judiciais serão cobradas segundo o disposto nas leis de regência no âmbito da Justiça Federal, da Justiça do Trabalho, da Justiça Militar, do Distrito Federal, dos Territórios e dos Estados, obedecidos os requisitos e limites estabelecidos nesta Lei.

Art. 3o. As custas judiciais, destinadas exclusivamente ao custeio dos serviços afetos às atividades específicas da Justiça e prestados exclusivamente pelo Poder Judiciário, têm por fato gerador a prestação de serviços públicos de natureza forense, devidas pelas partes.

Parágrafo único. É vedada a destinação de valores recolhidos a título de custas judiciais a pessoas jurídicas de direito público, de direito privado, instituições ou entidades de qualquer natureza.

Art. 4o. Caberá à União, na Justiça Federal, na Justiça do Trabalho e na Justiça Militar de primeiro e segundo graus; aos Estados e ao Distrito Federal estabelecer, em lei, as hipóteses e critérios de isenção das custas judiciais no seu âmbito.

Art. 5o. Salvo as exceções estabelecidas nesta Lei, na legislação federal, do Distrito Federal, dos Territórios, e nas leis estaduais específicas, as custas judiciais incidirão sobre o valor da causa em três fases distintas do processo:

I - no momento da distribuição;

II - como preparo da apelação, do agravo, do recurso adesivo e dos embargos infringentes, e nos processos da competência originária do tribunal;

III - ao ser proposta a execução.

$\S 1^{\circ}$. Nas fases previstas nos incisos I e III do caput deste artigo o percentual sobre o valor da causa não poderá exceder a $2 \%$ (dois por cento), em cada uma dessas fases e, na prevista no inciso II, o percentual sobre o valor da causa não poderá exceder a $4 \%$ (quatro por cento).

$\S 2^{\circ}$. Para efeito de cobrança das custas judiciais a soma dos percentuais a que se refere o parágrafo anterior não poderá ultrapassar o percentual de $6 \%$ (seis por cento), obedecidos, ainda, os limites mínimo, correspondente a 112,00 (cento e doze reais), e máximo, de 62.200,00 (sessenta e dois mil e duzentos reais), valores esses que serão reajustados no dia primeiro de janeiro de cada exercício, tendo por base o INPC - Índice Nacional de Preços ao Consumidor, do IBGE, nos últimos doze meses do exercício anterior. 
§3․ Nos pedidos de natureza condenatória o valor do preparo a que se refere o inciso II deste artigo será calculado sobre o valor fixado na sentença, se for líquido e certo. Não sendo líquido e certo, incidirá o valor mínimo previsto no parágrafo anterior.

$\S 4^{\circ}$. Para as ações em geral, medidas urgentes, antecipatórias, incidentes, com caráter satisfativo, que não revelem reflexo econômico próprio ou imediato, as custas serão cobradas segundo valores previamente estabelecidos em tabela própria editada pelo Tribunal.

§5ㅇ․ Nos inventários, arrolamentos, ações de divórcio e outras, em que haja partilha de bens ou direitos, as custas serão fixadas segundo o valor envolvido e não poderão exceder o limite máximo previsto no $§ 2^{\circ}$ deste artigo.

$\S 6^{\circ}$. Nas hipóteses de litisconsórcio ativo voluntário com mais de dez autores, poderá ser estabelecida parcela adicional, além dos valores previstos nos incisos I a III deste artigo, para cada grupo de dez autores ou fração que exceder a primeira dezena.

§7ㅇ. Não haverá incidência de custas na interposição do agravo retido e do agravo contra decisão denegatório de recursos extraordinário e especial.

Art. 6ㅇ. As disposições do artigo anterior não se aplicam à Justiça do Trabalho, que se submete ao regime estabelecido nos arts. 789, 789-A, 789-B, 790, 790-A e 790-B da Consolidação das Leis do Trabalho - CLT, aprovada pelo Decreto-Lei no 5.452, de 1o de maio de 1943, com redação da Lei 10.537, de 27 de agosto de 2002.

Art. 7‥ Quando o processo ficar parado durante mais de 1 (um) ano por negligência das partes, pagarão elas proporcionalmente as custas devidas, em percentual que não exceda a $2 \%$ (dois por cento) do valor da causa.

Parágrafo Único. $\mathrm{O}$ abandono, a desistência do feito ou a transação que ponha termo ao processo, em qualquer fase, não dispensa o pagamento das custas, nem dá direito à restituição.

Art. 8․ O acesso aos Juizados Especiais e ao Juizado da Fazenda Pública independerá, em primeiro grau de jurisdição, do pagamento de custas, taxas ou despesas, nos termos da legislação (Lei 9.099/95; Lei 10.259/2001 e Lei 12.153/2009).

Art. 9․ Nas ações penais em geral, as custas judiciais serão pagas ao final pelo acusado, se condenado, em valor que não ultrapasse o limite de 24.880,00 (vinte e quatro mil, oitocentos e oitenta reais) corrigidos anualmente segundo o critério estabelecido no $\S 2$ o . do art. 5ㅇ․

Parágrafo único. Nas ações penais privadas, respeitado o limite estabelecido no "caput" deste artigo e a critério dos tribunais, as custas poderão ser recolhidas de uma só vez, ou da seguinte forma: 
a) cinquenta por cento (50\%) no momento da distribuição, ou, na falta desta, antes do despacho inicial;

b) cinquenta por cento (50\%) no momento da interposição de recurso cabível.

Art. 10. Respeitado o disposto no art. $4^{\circ}$, não serão cobradas custas judiciais nas causas relativas aos feitos referidos nos incisos deste artigo, enquanto a lei de regência assim determinar:

I - nos processos de habeas corpus (art. 654 do DL 3.689, de 03.10.41) e habeas data (art. 21 da Lei 9.507, de 12.11.97);

II - nas causas relativas à jurisdição de infância e juventude, ressalvada a litigância de má-fé (art. 141, § da Lei 8.069, de 13.07.1990), salvo as hipóteses que não envolvam interesses de crianças e adolescentes; III - nas ações de acidentes do trabalho sob a regência da Lei 8.213, de 24.07.1991 (art. 129, parágrafo único);

IV - nas ações de alimentos e nas ações revisionais de alimentos, propostas pelo alimentando, em que o valor da prestação mensal pretendida não seja superior a um salário-mínimo e meio (Lei 5.478, de 25.07.68, art. $\left.1^{\circ}, 2^{\circ} \stackrel{\circ}{ }\right)$.

Art. 11. Nas ações populares e civis públicas, as custas serão devidas pelo réu, se condenado, e pelo autor, se comprovada má-fé (CF/88, art. 5으, inc. LXXIII).

Art. 12. As custas judiciais abrangem todos os atos processuais, inclusive os relativos aos serviços de distribuidor, serventias judiciais de primeira instância, contador, partidor, de hastas públicas, da Secretaria dos Tribunais, bem como as despesas com registros, intimações e publicações na Imprensa Oficial.

$\S 1^{\circ}$. Nas custas judiciais não se incluem:

I - as publicações de editais;

II - as despesas com a expedição de cartas rogatórias, de ordem e precatórias, com o porte de remessa e de retorno dos autos, no caso de recurso e o desarquivamento de autos de processos judiciais, cujos valores serão estabelecidos por ato do Conselho da Magistratura; 
III - as despesas postais realizadas através da Empresa Brasileira de Correios e telégrafos;

IV - a comissão dos leiloeiros e assemelhados;

V - a expedição de certidão, cartas de sentença, de arrematação, de adjudicação, e a reprodução de peças do processo, cujos custos serão fixados periodicamente pelo Conselho da Magistratura;

VI - a remuneração do perito, assistente técnico, avaliador, depositário, leiloeiro, tradutor, intérprete e administrador;

VII - a indenização de viagem e diária de testemunha;

VIII - as consultas de andamento dos processos por via eletrônica, ou da informática;

IX - as despesas de diligências dos Oficiais de Justiça, salvo em relação aos mandados:

a) expedidos a requerimento do Defensor Público;

b) do interesse de beneficiário de assistência judiciária;

$\mathrm{X}$ - todas as demais despesas que não correspondam aos serviços relacionados no "caput" deste artigo.

$\S 2$. . O valor do ressarcimento das despesas de condução dos Oficiais de Justiça, não incluído nas custas, será estabelecido pelo Corregedor Geral da Justiça, devendo o pagamento ser feito por ocasião de cada ato processual, competindo à parte interessada adiantar as despesas relativas a atos, cuja realização o juiz determinar de ofício ou a requerimento do Ministério Público.

$\$ 3$. Compete ao autor adiantar as despesas relativas a atos cuja realização o juiz determinar de ofício ou a requerimento do Ministério Público.

Art. 13. As custas previstas nesta lei não excluem as despesas estabelecidas na legislação processual em vigor.

Art. 14. O recolhimento das custas judiciais poderá será diferido para depois da satisfação da execução ou para momento oportuno, quando comprovada, por meio idôneo, a momentânea impossibilidade financeira do seu recolhimento, ainda que parcial:

I - nas ações de alimentos e nas revisionais de alimentos;

II - na ação declaratória incidental;

III - em outras hipóteses que a lei local estabelecer.

Art. 15. O pagamento das custas judiciais devidas à União, na Justiça Federal de primeiro e segundo graus, nos Estados, no Distrito Federal e Territórios Federais será efetuado no Banco do Brasil ou na Caixa Econômica 
Federal, mediante documento de arrecadação das receitas federais, ou documento similar estabelecido pela Secretaria do Tesouro Nacional.

Art. 16. O pagamento das custas judiciais no âmbito dos Estados é feito mediante documento próprio de arrecadação e será depositado em nome do tribunal respectivo em banco oficial do Estado e, onde não houver, no Banco do Brasil ou na Caixa Econômica Federal.

Parágrafo único. A escolha da instituição financeira depositária, nos termos do caput deste artigo e quando não houver banco oficial do Estado, deverá ser feita através de licitação, na modalidade "convite", nos termos do art. 22, §3ํㅡ da Lei no 8.666, de 21 de junho de 1993.

Art. 17. Nas Varas do Trabalho, nos Juízos de Direito investidos de jurisdição trabalhista, nos Tribunais Regionais e no Tribunal Superior do Trabalho, a forma de pagamento das custas e emolumentos obedecerá às instruções que serão expedidas pelo Tribunal Superior do Trabalho.

Art. 18. Rege-se pela legislação estadual respectiva a cobrança de custas nas causas ajuizadas perante a Justiça Estadual, no exercício da jurisdição federal.

Art. 19. A conta especial que abrigará o produto da arrecadação das custas judiciais terá escrituração própria, atendidas as normas previstas na legislação vigente e estará sujeita à auditoria do Tribunal de Contas respectivo.

§1‥ O controle de arrecadação das custas em conta única; a fiscalização do disposto no art. 5ํㅡ, LXXIV da Constituição Federal e o acompanhamento do efetivo e correto recolhimento das custas judiciais compete, respectivamente, ao Presidente do Tribunal, ao magistrado que preside o processo e ao titular da serventia judicial, com a supervisão do Conselho da Magistratura, do Órgão Especial ou do Tribunal Pleno.

§2‥ No prazo de 60 (sessenta) dias, contado da promulgação desta Lei, os tribunais, por seu Tribunal Pleno ou Órgão Especial, editarão os atos necessários à supervisão de arrecadação e fiscalização do recolhimento das custas judiciais em seu âmbito.

§3‥ O Presidente do Tribunal enviará ao Órgão Especial ou Tribunal Pleno, até o dia 15 de dezembro de cada exercício, relatório circunstanciado e prestação de contas dos valores arrecadados mês a mês no exercício e o seu montante, com comparativo de arrecadação nos últimos três anos, que deverá ser publicado no Diário Oficial por três vezes em dias alternados.

Art. 20. Os tribunais deverão publicar uma vez por ano o seu Regimento de Custas e respectivas tabelas na Imprensa Oficial e mantê-lo em seu sítio eletrônico da Internet ("Site") permanentemente e atualizado. 
Art. 21. As disposições contidas em leis estaduais que estabelecem o regime de cobrança de valores para o custeio dos serviços afetos às atividades específicas da Justiça, sob a denominação de taxa judiciária, ficam mantidas, desde que observados os critérios e limites estabelecidos nesta Lei.

Parágrafo único. É vedada a distinção entre custas judiciais e taxa judiciária para efeito de cobrança de valores em duplicidade, decorrentes do mesmo fato gerador.

Art. 22. Até a vacância dos respectivos cargos, os valores arrecadados pelas serventias judiciais privatizadas, nos termos desta lei, pertencem aos seus titulares.

Parágrafo único. Nas mesmas condições do caput, os valores devidos pelos atos praticados pelos distribuidores privatizados estão excluídos da limitação do art. 12.

Art. 23. O Conselho Nacional de Justiça fiscalizará o cumprimento desta Lei pelos tribunais.

Art. 24. Esta Lei entra em vigor 180 (cento e oitenta) dias após sua publicação e produzirá efeitos a partir de 1o de janeiro do ano seguinte.

Parágrafo único. No prazo de 90 (noventa) dias contados da publicação desta lei na Imprensa Oficial, os Tribunais deverão enviar ao Poder Legislativo os projetos de leis de custas visando sua compatibilização com esta lei.

Brasília, 15 de outubro de 2012.

\section{Conselheiro JEFFERSON KRAVCHYCHYN Relator}

